\title{
Modeling techniques in counseling in high school to improve the behavior prosocial
}

\author{
Nina Permata Sari ${ }^{1}$, Muhammad Andri Setiawan $^{2}$, Rosida Andriani ${ }^{3}$ \\ ${ }^{123}$ Universitas Lambung Mangkurat
}

\begin{tabular}{l}
\hline \hline Article Info \\
\hline Article history: \\
Received Feb 28th, 2020 \\
Revised May 23th, 2020 \\
Accepted Jun 6th, 2020
\end{tabular}

Keyword:

Modeling techniques,

Prosocial behavior,

Students

\begin{abstract}
The development of the technological era 4.0 which has an impact on the erosion of individual awareness of the social environment is characterized by low prosocial behavior. Alternative solutions offered to improve prosocial behavior through the use of modeling techniques, by using this technique the goal achieved is to improve the ability of prosocial behavior in high school students. This study took place in SMAN 9 Banjarmasin, based on the distribution of questionnaires obtained by 6 students who have low prosocial behavior. Based on the results of the investigation statistically, the results show the value of $z=-2.201$ while for the value of $z t a b=-0.0139$, which means zhit $>$ ztab so that $\mathrm{Ha}$ is accepted and at the Asymp value. Sig. (2-tailed) $=$ $0.028<0.05=0.05 \%$ so that it can be interpreted as modeling techniques that can improve the ability of prosocial behavior. Therefore, modeling techniques can be relied upon to improve prosocial behavior.
\end{abstract}

(C) 2020 The Authors. Published by Indonesian Institute for Counseling,

Education and Therapy (IICET). This is an open access article under the CC BY license (https://creativecommons.org/licenses/by/4.0/)

\section{Corresponding Author:}

Muhammad Andri Setiawan

Universitas Lambung Mangkurat

Email: andri.bk@ulm.ac.id

\section{Introduction}

The impact of the 4.0 revolution on the social sector made a big change in the way people think. Social interaction is unlimited, because of the ease of internet access and technology. Social relations of community relations are now more closely developed in cyberspace so that relationships in the real world become relative (Prasetyo \& Trisyanti, 2018). In the same view industrial growth 4.0 shifted moral and ethical boundaries in society to become more individualistic and lack social sensitivity (Morrar, Husam \& Mousa, 2017).

As social creatures, humans always need other people and need social interaction with the surrounding environment in meeting the needs of their lives. One form of positive social interaction is associative social interaction or generating cooperation, the cooperation in question is to jointly carry out unison work in, such as repairing roads, community service to clean the environment, light-handed to help others in distress (Susanto, 2018). Prosocial behavior can intensively change the physical state of and psychological the recipient of assistance from the less good to be better, both materially and or psychologically, in other words, prosocial behavior has a positive effect to help improve well-being in individuals. Another advantage of prosocial behavior is that perpetrators of prosocial behavior can foster empathy, increase altruism, respect others and foster positive attitudes (Donald, Sahdra, Van Zanden, Duineveld, Atkins, Marshall, \& Ciarrochi, 2019).

The highest prosocial behavior tends to be at the end of childhood aged 8-10 years, then gradually decreases in adolescents aged 11-18 years, and if this is not given guidance it will settle into adulthood aged 19 years and above (Knoll, Leung, Foulkes, \& Blakemore, 2017; Foulkes, Leung Fuhrmann, Knoll, \& Blakemore, 2018). The study found that social influences in adolescence tend to be more directed to negative outcomes such as antisocial behavior, drugs, speeding on the street (Knoll, Magis-Weinberg, Speekenbrink \& 
Blakemore, 2015). Yet another study states that adolescents can be very easily influenced by positive social behavior, and there is social development in adolescents who have positive consequences (Hoorn, Fuligni, Crone, Eveline \& Galvan, 2016).

Prosocial can be formed from parenting patterns, democratic parenting tends to form positive prosocial while authoritarian parenting tends to form negative prosocial (Carlo, White, Stress, Knight, \& Zeiders, 2018). Other findings in adolescence are developmental stages that are making early changes, requiring attention, support and knowledge about behavior adaptive that is appropriate to the stage of their developmental age so that at this age educators and parents can easy to give examples and guidance of prosocial behavior in adolescents (Seniasih, Tirka \& Suranata, 2019). Parents who fully involve the process of growth and self-development of adolescents contribute to the formation of adolescent prosocial behavior (Carlo, White, Stress, Knight, \& Zeiders, 2018). Because parents are the first model that children see and imitate. Modeling has a strong relationship of how patterns of thinking and behavior are formed based on the identification of models in the family, especially the figures of parents who tend to be role models of children (Coulombe, Rudd \& Yates, 2019).

Modeling techniques can develop adolescent attitudes in interacting with the opposite sex in Vocational Prshanti Nilayam Bali through symbolic modeling by observing videos that are considered relevant (Apriliana, Suarni \& Dharsana, 2019). Modeling with video media content can construct adolescent thinking patterns because all five senses directly absorb the information received (Keumala, Nurihsan \& Budiamin, 2018). Behavioral counseling with modeling techniques can change the mindset of students or treatment subjects that will be followed by changes in behavior. Modeling techniques can also be used by models in fellowship with selected teenagers through lesson study (Seniasih, Suranata \& Darsana, 2019). Based on this, it can be assumed that the change and development of adolescent character can be carried out in the process of orientation of prosocial behavior with modeling techniques.

Komalasari \& Wahyuni (2014: 179-180) explains that there are some steps implemented in the modeling process, although it is not regulated by default including (1) determination of live models, symbolic models, multiple models; (2) on the live model, select a friendly model or counselee peers who have similarities such as age, economic status, and physical appearance; (3) if possible use more than one model; (4) the complexity of the behavior being modeled must be following the level of the counselee's behavior; (5) combine modeling with rules, instructions and reinforcement; (6) when the counselee pays attention to the character's appearance, it gives natural reinforcement; (7) if possible create training designs for counselees to imitate the model correctly so that it will direct the counselee to natural reinforcement. If not, then make a plan for giving reinforcement for every imitation of the right behavior; (8) if the behavior is complex, then the modeling stage is carried out starting from the easiest to the more difficult; (9) the modeling scenario must be realistic and final; (10) modeling where the character shows behavior that does not cause fear for the counselee (with a sweet attitude, attention, soft language, and pleasant behavior counselee).

In a preliminary study in class XI teenagers at SMAN 9, the documentary data on personal development reports of class XI students in the 2018/2019 school year by researchers showed a tendency for prosocial behavior to be low, with indicators showing students who came to do school work, students who were often absent on duty picket cleaning class, and low awareness to help friends if they have difficulties. If this behavior is not immediately carried out curative services in the field of guidance and counseling services by the Guidance and Counseling teacher, the impact is that adolescents will achieve developmental tasks at their present age level, which is the aspect of responsible development in people's lives and upholds community values in acting behavior (Astuti, 2017, 13 August). Prosocial behavior is related to perspectivetaking, empathy and emotional regulation skills (Mares, 2017). Prosocial behavior can encourage student success in academic achievement (Flook, Waxler \& Davidson, 2019). To be able to help improve prosocial behavior in students, one of the appropriate counseling services is group counseling with modeling techniques, this study aims to investigate the orientation process of modeling techniques in improving the ability of prosocial behavior in students of SMAN 9 Banjarmasin.

\section{Method}

This research approach is a research approach quantitative, a type of experimental research. In this experimental research using the quasi-experimental design method with the form of Nonequivalent Control Group Designs (Sugiyono, 2015). 
This design can be described as follows:

Table 1. Nonequivalent control group designs

\begin{tabular}{ccc}
\hline \multicolumn{3}{c}{ Nonequivalent Control Group Designs } \\
\hline Pretest & Treatment & Posttest \\
\hline $\mathrm{O}_{1}$ & $\mathrm{X}$ & $\mathrm{O}_{2}$ \\
$\mathrm{O}_{3}$ & - & $\mathrm{O}_{4}$ \\
\hline
\end{tabular}

Description: Effect of modeling techniques on prosocial behavior in students $=\left(\mathrm{O}_{2}-\mathrm{O}_{1}\right)-\left(\mathrm{O}_{4}-\mathrm{O}_{3}\right)$

This study has the independent variable $(\mathrm{X})$ which is a modeling technique and the dependent variable (Y), namely prosocial behavior. The place of this research took place at SMAN 9 Banjarmasin. The Subjects' research were students of class XI of SMAN 9 Banjarmasin. The total population of 208 students, which then carried out sampling using a purposive sampling technique, based on the sampling criteria obtained 6 samples, which have low prosocial behavior, then the sample is divided into two groups, namely the control group of 3 samples and the group of 3 samples.

\section{Results and Discussion}

Data collection instruments in this study used a scale of prosocial behavior variables with measurement indicators: helping behavior, providing benefits to people who are helped, physical and psychological assistance and not demanding benefits from people who are helped (Dayakisni \& Hudaniah, 2015). The instrument for implementing modeling techniques. Before analyzing the data, a normality test and a homogeneity test are performed using SPSS (Statistical Product and Service Solutions) for Windows version 22. Furthermore, a data analysis technique is performed using the Wilcoxon Test (Sugiyono, 2015).

Based on the results of research for the measurement of prosocial behavior (pre-test) given to 208 students of class XI at SMAN 9 Banjarmasin. Obtained for prosocial behavior results before being given group counseling with modeling techniques namely 15 students have a very high category, 152 students have a high category, 26 students have a medium category, 6 students have a low category, 0 students have a very low category, while 9 students were not present at the time of measurement.

Table 2. Percentage of Prosocial Behavior

\begin{tabular}{clccl}
\hline No & \multicolumn{1}{c}{ Category } & Frequency of & Presentation & \multicolumn{1}{c}{ Remarks } \\
\hline 1. & Very Low & 0 & $0 \%$ & None \\
2. & Low & 6 & $3 \%$ & Smallest portion \\
3. & Medium & 26 & $13 \%$ & Smallest portion \\
4. & High & 152 & $73 \%$ & Most \\
5. & Very High & 15 & $7 \%$ & The smallest part of the \\
\hline
\end{tabular}

\section{Validity Test Results from the validity}

A test used in this study is the internal validity test that is to correlate the scores of each item instrument in the total score. The formula used is the Product Moment. Based on the results of the validity test of an instrument the prosocial behavior, the instrument consisted of 78 items distributed to 36 students and the results obtained were 13 invalid items.

\section{Reliability Test Results}

Based on the results of the reliability test using Alpha Cronbach with a significance level of $5 \%$ the results obtained are $r$ count $0.9428(0.943)$, while the $r$ table is 0.183 . Because $r$ arithmetic $>r$ table it can be concluded that the scale is reliable.

\section{Normality Test Results}

Based on the normality test that has been done, the Shapiro-Wilk test values obtained Sig. 0.505 and $0.863>$ 0.05 so that it can be concluded that the data from the population are normally distributed. 
Table 3. Results of Normality Test

\begin{tabular}{|c|c|c|c|c|c|c|}
\hline \multicolumn{7}{|c|}{ Tests of normality } \\
\hline \multirow{2}{*}{ Period } & \multicolumn{2}{|c|}{ Kolmogorov-Smirnov } & & \multicolumn{2}{|c|}{ Shapiro-Wilk } & \multirow[b]{2}{*}{ Sig. } \\
\hline & Statistic & Df & Sig. & Statistics & Df & \\
\hline Pretest &, 180 & 6 & $200^{*}$ &, 920 & 6 &, 505 \\
\hline Posttest &, 147 & 6 &, $200^{*}$ & , 966 & 6 &, 863 \\
\hline
\end{tabular}

*. This is a lower bound of true significance.

a. Lilliefors Significance Correction

\section{Homogeneity Test}

Table 4. Homogeneity Test

F-Test Two-Sample for Variance

\begin{tabular}{lrr}
\hline & Pretest & Posttest \\
Mean & 141.6666667 & 173.1666667 \\
Variance & 2.666666667 & 199.7666667 \\
Observations & 6 & 6 \\
Df & 5 & 5 \\
F & 0.013348907 & \\
P (F <= f) one-tail & 0,000106674 & 0.1980069 \\
F Critical one-tail & 0.106 & \\
\hline
\end{tabular}

Measurement Results Pre and Post Test Group Test Experiment

Table 5. Results of Pre Test and Post Test for the experimental group

\begin{tabular}{ccccccc}
\hline \multirow{2}{*}{ Counselee } & \multicolumn{4}{c}{ Score\% } & \multicolumn{2}{c}{ Description } \\
\cline { 2 - 6 } & Pre & Post & Pre & Post & Pre & Post \\
\hline 1 & 142 & 198 & $55 \%$ & $76 \%$ & Low & High \\
2 & 140 & 177 & $54 \%$ & $68 \%$ & & Low-Medium \\
3. & 143 & 188 & $55 \%$ & $72 \%$ & Low & High \\
\hline
\end{tabular}

Pre Test and Post Test Measurement Results Control Group

Table 6. Pre Test and Post Test Results for the Control Group

\begin{tabular}{ccccccc}
\hline & \multicolumn{2}{c}{ Score } & \multicolumn{2}{c}{$\%$} & \multicolumn{2}{c}{ Description } \\
\cline { 3 - 7 } Counsel & Pre & Post & Pre & Post & Pre & Post \\
4. & 144 & 160 & $55 \%$ & $62 \%$ & Low & Medium \\
5. & 140 & 170 & $54 \%$ & $65 \%$ & Low & Medium \\
6. & 141 & 155 & $54 \%$ & $60 \%$ & Low & Medium \\
\hline
\end{tabular}

\section{Hypothesis Testing}

Based on the results of the Wilcoxon test using SPSS 22, the results are obtained:

Table 7. Wilcoxon Test Results

\begin{tabular}{|c|c|c|c|c|}
\hline & & $\mathbf{N}$ & Mean Rank & Sum of Ranks \\
\hline \multirow[t]{4}{*}{ posttest - pretest } & Negative Ranks & $0^{\mathrm{a}}$ &, 00 &, 00 \\
\hline & Positive Ranks & $6^{\mathrm{b}}$ & 3,50 & 21,00 \\
\hline & Ties & $0^{c}$ & & \\
\hline & Total & 6 & & \\
\hline
\end{tabular}

a. posttest <pretest 
b. posttest $>$ pretest

c. posttest $=$ pretest

Table 8. Wilcoxon Results

\section{Test Statistics}

\section{Z}

posttest - pretest

Asymp. Sig. (2-tailed)

a. Wilcoxon Signed Ranks Test

b. Based on negative ranks.

Table 8 shows that the process of modeling techniques has proven to be effective and can be used to improve prosocial behavior.

There are differences in the results of prosocial behavior from the experimental group with the control group, that for the experimental group there was a significant increase for prosocial behavior from the low category to increase to high, whereas for the control group the increase occurred but was less significant ie from the low category increased to moderate. The increase in the experimental group was influenced by the counseling technique used, namely the modeling technique. This is based on the modeling technique that teaches individuals to learn to create and implement new behaviors through the process of observing, generalizing other behaviors, involving cognitive and creative processes rather than merely imitating (Fuadi, Lutfi, Gading \& Darsana, 2019). Individuals can become cruisers because the environment provides examples that students can observe and process cognitively to behave (Kumru, Carlo, Mestre \& Samper, 2012).

In the orientation process given in the group experimental, the counselees internalize the values of prosocial behavior into their thought processes which the counselee then discusses together with the counselor, and is strengthened by the counselor to be immediately applied into their behavior. It turns out that a positive relationship between the teacher (counselor) and students (counselee) also supports the rapid success of the desired positive behavior (Carlo, White, Stress, Knight, \& Zeiders, 2018). Therefore the role of the counselor becomes important to create a flow of positive prosocial behavior. Group members learn to express feelings, respect each other, show concern, share experiences, increase self-confidence (Astuti, 2012; I Chitra \& Noor, 2019).

The importance of role models for adolescents helps guide the development of positive characters for adolescents (Keumala, Nurihsan \& Budiamin, 2018). Teenagers tend to imitate the model shown to them repeatedly, meaning that someone will become an altruist because the environment provides a real example, seen directly by individuals (Pambudi, Mulawarman \& Japar, 2019). Because a lot of human behavior is formed through the process of imitating. Moreover, prosocial behavior has a priming effect by associating with positive views about human traits in the observer (Li Wen-Qiao, Li Liman Man Wai \& Li Ming, 2019). The latest finding in this study is that prosocial behavior is formed not only from modeling the social environment but also if it is not fully supported by prosocial interests in individuals it will be difficult to internalize the behavior, tendencies can be formed but only temporary. So that in further studies before applying this modeling technique, counselors need to attract counselees to be motivated to have prosocial behavior in themselves. The view of this finding is supported by Futamura (2018) that prosocial behavior is formed not only because of a large environmental influence but also supported by an interest in greater prosocial behavior. This is evident from the results of the control group that increased prosocial behavior, namely the increase factor was more influenced because they were interested in doing prosocial behavior on themselves.

\section{References}

Apriliana, I Putu Agus, Suarni Ni Ketut \& Dharsana, I Ketut. (2019). The Effectiveness of the Symbolic Modelling Technique for Intervening the Low Promiscuity of Students. Bisma The Journal of Counseling. 3 (1), 1-06, from http://dx.doi.org/10.23887/bisma.v3i1.17910.

Astuti, Budi. (2012). Modul konseling kelompok. Yogyakarta: Fakultas Ilmu Pendidikan Universitas Negeri Yogyakarta. 
Astuti, Dewi Anita. (2017, 13 August). Optimalisasi peran guru bimbingan dan konseling dalam menguatkan nilainilai moral remaja yang berkarakter. Paper presented at Seminar Nasional Bimbingan dan Konseling in Universitas Ahmad Dahlan, Yogyakarta, Indonesia. Retrieved from http://seminar.uad.ac.id/index.php/snbkuad/article/view/57/62.

Carlo, G, White, RMB, Streit, C, Knight, GP, \& Zeiders, KH. (2018). Longitudinal Relations Among Parenting Styles. Prosocial Behaviors, and Academic Outcomes in U.S. Mexican Adolescents. Child Development, 89 (2), 577-592, from doi: 10.1111/cdev.12761.

Coulombe, Brianne R, Rudd Kristen L. \& Yates, Tuppett M. (2019). Children's Physiological Reactivity in Emotion Contexts and Prosocial Behavior. Journal Brain and Behavior, 9(10), 1-16, from doi: $10.1002 /$ brb3.1380.

Dayakisni, Tri \& Hudaniah. (2009). Psikologi sosial. Malang: UMM Press.

Donald, JN, Sahdra, BK, Van Zanden, B, Duineveld, JJ, Atkins, PWB, Marshall, SL, \& Ciarrochi, J. (2019). Does Your Mindfulness Benefit Others? A systematic Review and Meta-analysis of the Link Between Mindfulness and Prosocial Behaviour. British Journal of Psychology, 110 (1), 101-125, from doi: 10.1111/bjop. 12338 .

Flook, Lisa, Waxler, Zahn Carolyn \& Davidson, J, Richard. (2019). Developmental Differences in Prosocial Behavior Between Preschool and Late Elementary School. Front Psychology, 3, 9-12, from https://doi.org/10.3389/fpsyg.2019.00876.

Foulkes, L, Leung, JT, Fuhrmann, D, Knoll, LJ, \& Blakemore, SJ (2018). Age Differences in the Prosocial Influence Effect. Journal of Developmental Science, 21 (6), 1-9, from doi: 10.1111/desc. 12666.

Fuadi, Luthfi, Gading, Ketut \& Darsana, Ketut. (2019, 22-25 July). Effectiveness of the application of counseling theory behavioral with modelling techniques to increase the desire to solve something well and successfully through lesson study in Sukasada. Paper presented at International Conference on Technology and Educational Science in Nagoya University, Nagoya, Japan. Retrieved from https://doi.org/10.32698/40297.

Futamura, Ikumi. (2018). Is Extraordinary Prosocial Behavior More Valuable than Ordinary Prosocial Behavior? PLoS ONE, 13(4), 1-15, from https://doi.org/10.1371/journal.pone.0196340.

Hoorn, Jorien van, Fuligni, Andrew J, Crone, Eveline A, \& Galvan, Adriana. (2016). Peer Influence Effects on Risk-taking and Prosocial Decision-making in Adolescence: Insights from Neuroimaging Studies. Current Opinion in Behavioral Sciences, 10, 59-64, from https://doi.org/10.1016/j.cobeha.2016.05.007.

I, Chitra C \& Noor, M. (2019). Development of Guidance and Counseling Model Service with Bibliotherapy Techniques to Improve Prosocial Behavior for Student of Primary School. Journal of Physics: Conference Series 1179, 1-6, from doi:10.1088/1742-6596/1179/1/012060.

Keumala, Elsa, Nurihsan, Juntika \& Budiamin, Amin. (2018). The Development of Career Learning Program with Modelling Techniques to Improve Student Career Awareness. Islamic Guidance and Counseling Journal, 1 (1), 53-61, from https://doi.org/10.25217/igcj.v1i2.270.

Knoll, Lisa J., Leung, Jovita T., Foulkes, Lucy, \& Blakemore, Sarah-Jayne. (2017). Age-related Differences in Social Influence on Risk Perception Depend on the Direction of Influence. Journal of Adolescence, 60, 53-63, from https://doi.org/10.1016/j.adolescence.2017.07.002.

Knoll, Lisa J., Magis-Weinberg, Lucía, Speekenbrink, Maarten, \& Blakemore, Sarah-Jayne (2015). Social Influence on Risk Perception During Adolescence. Psychological Science, 26 (5), 583-592, from doi: 10.1177/0956797615569578.

Komalasari, Gartina \& Wahyuni, Eka. (2014). Teori dan Teknik Konseling. Indeks: Jakarta.

Kumru, Asiye, Carlo, Gustavo, Mestre, Maria V \& Samper, Paula. (2012). Prosocial Moral Reasoning and Prosocial Behavior Among Turkish and Spanish Adolescents. Social Behavior and Personality, 40(2), $205-$ 214, from doi:10.2224/sbp.2012.40.2.205.

Li Wen-Qiao, Li Liman, Man, Wai, \& Li, Ming. (2019). Residential Mobility Reduces Ingroup Favouritism in Prosocial Behavior. Asian Journal of Social Psychology, 22, 3-17, from doi: 10.1111/ajsp.12338. 